\title{
Viral glycoproteins: biological role and application in diagnosis
}

\author{
Nilotpal Banerjee $^{1} \cdot$ Sumi Mukhopadhyay ${ }^{1}$
}

Received: 21 September 2015/Accepted: 10 December 2015/Published online: 18 January 2016

(C) Indian Virological Society 2016

\begin{abstract}
The viruses that infect humans cause a huge global disease burden and produce immense challenge towards healthcare system. Glycoproteins are one of the major components of human pathogenic viruses. They have been demonstrated to have important role(s) in infection and immunity. Concomitantly high titres of antibodies against these antigenic viral glycoproteins have paved the way for development of novel diagnostics. Availability of appropriate biomarkers is necessary for advance diagnosis of infectious diseases especially in case of outbreaks. As human mobilization has increased manifold nowadays, dissemination of infectious agents became quicker that paves the need of rapid diagnostic system. In case of viral infection it is an emergency as virus spreads and mutates very fast. This review encircles the vast arena of viral glycoproteins, their importance in health and disease and their diagnostic applications.
\end{abstract}

Keywords Viral glycoprotein · Immunodiagnostics · Biomarker · Viral pathogenesis

\section{Introduction}

Being an obligate intracellular parasite [32], virus is the most deadly microbe to be dealt with. Globally it accounts for extremely high morbidity and mortality throughout the age groups of people [3, 62]. Thousands of new viral strains are discovered till date affecting people producing a

Sumi Mukhopadhyay

drsumimukhopadhyay@gmail.com

1 Department of Laboratory Medicine, School of Tropical Medicine, 108, C.R Avenue, Kolkata 700073, India huge global burden of viral infections resulting immense challenge towards healthcare system $[9,20,48]$. With the capability of fast mutation, viruses affect the host cells with new and newer mechanisms. So to detect them at the earliest, there is an extreme need of dynamic diagnostic system.

Glycans are major components of the outermost surface of viruses. Thus, majority of the interactions of viral pathogens with their hosts are influenced by the pattern of glycans and glycan-binding receptors that each expresses. $[5,95,98]$ Glycans are most complex biomolecules due to extensive branching of carbohydrates, and a variety of glycoproteins have been identified in human viral pathogens. These pathogenic glycans either virus encoded or host derived usually elicit high humoral responses in human body [34]. These virus specific high levels of glycan specific antibodies have been exploited to develop novel diagnostic assays.

Viral diagnostic tests can be broadly classified into three categories in general. Those are direct detection, indirect examination (virus isolation), and by serology. In case of direct detection, the clinical sample is examined directly to identify any presence of virus particles, virus antigen or viral nucleic acids. In case of indirect examination, the sample has to be added into cell culture, eggs or animals to grow the virus in vitro. This is known as virus isolation. Serology always constitutes the bulk of the work of any virology laboratory, especially in overpopulated third world countries. Serological diagnosis is generally made by detecting titres of antibody in infection [8]. Generally, the majority of common viral infections are diagnosed by serology [86]. Viruses can be directly detected through electron microscopy. It can also be enumerated by molecular biological techniques like PCR/RTPCR by detecting viral genomes. These techniques are extremely 
useful but are technically demanding, costly and require skilled personnel. On the other hand, indirect detection by virus isolation is dependent on cell culture techniques. The major problem of cell culture is it takes a long time (up to 4 weeks). Also, the sensitivity is poor and depends on many factors, such as the specimen condition and the condition of the cell line. Cell cultures are also very susceptible to microbial contamination and toxins present in the specimen. Also, many viruses do not grow at all in cell culture e.g. Hepatitis B and C, viruses causing diarrhea, parvovirus etc. Serology is the mainstream of viral diagnosis $[8,44]$. With increase in the growth of sophisticated immunoassay techniques, effective viral immunodiagnostic assays are now available in the market [13, 91, 96].

The detection of structural glycoproteins of viruses or early glycoprotein antigen formation in the host due to viral infection or the quantification of titres of antibodies against viral antigenic glycoprotein is an emerging discipline in viral immunodiagnostics [47]. The detection of these structural glycoproteins of viruses is done by lectins or monoclonal antibodies acting as probe or by measuring the titres of host antibodies against antigenic glycoprotein.

There are several good review works on viral glycoproteins. Namely, the work of Kazuya I.P.J. Hidari and Takashi Suzuki on Glycan receptor in influenza Virus [43]. Yuan et al. [116] worked on receptor glycoprotein interaction in Zaire Ebola Virus (ZEV). This review attempts to conglomerate the importance of glycoprotein in widely studied viral infection and their application in diagnosis.

\section{Viral glycoproteins}

A fully assembled infectious virus is known as virion. The simplest virions consist of two basic components, namely nucleic acid (single- or double-stranded RNA or DNA) and a capsid, which is a protein coat, functions as a shell to protect the viral genome from nucleases. This capsid comes into play during infection to attach the virion to specific receptors exposed on the prospective host cell. Capsid proteins are coded by the viral genome. Due to its limited size, the genome codes for only a few structural proteins (besides non-structural regulatory proteins involved in virus replication). Capsids are formed as single or double protein shells and consist of only one or a few structural protein species. Therefore, multiple protein copies must self assemble to form the continuous three-dimensional capsid structure [35]. The structural viral proteins are extremely important to the virus, so as to facilitate the transfer of the viral nucleic acid from one host cell to another. The proteins determine the antigenicity of the virus. Host's primary immune response is directed against the antigenic determinants of these proteins rather glycoprotein in major cases.

There are enveloped Viruses and these envelopes are made up of either lipid or glycoprotein. Viral envelopes mainly consist of Envelope proteins (E), Membrane proteins (M) and Spike proteins (S) [24]. Lipid envelopes are derived from the host cell. Whereas the envelope glycoproteins are virus encoded. However, there are sugars attached to the viral glycoproteins which often reflect the host cell that harboured the virus. The surface glycoproteins of an enveloped virus attach the virion to a target host cell by properly interacting with a cellular receptor [22]. Structural biological analysis of viral envelope glycoproteins reveals that viruses have wide range of folds to facilitate their attachment with proper host receptors. Bowden et al. [10] stated that Arenaviridae group of viruses have $\alpha / \beta$ fold, whereas Filoviridae possess 'Chalice' of GP1. Similarly, Paramyxoviridae shows six bladed $\beta$ propeller and large trimeric haemaglutinin is shown by Orthomyxoviridae. Glycosylated GP120 trimer is observed in the Lentiviruses of Retroviridae. Viruses exhibit 'Semaphorins' which are family of cell surface signalling glycoproteins [19]. These semaphorins binds with cell surface receptors to initiate important physiological processes. These observations are made by recent study of viral glycoproteins by employing Macromolecular crystallography [10]. The $\mathrm{M}$ and $\mathrm{S}$ proteins of the virus are usually rich in $\mathrm{N}$ glycosylated proteins, which have been demonstrated as important virulent factor of viruses [98]. Thus, E, M and S viral glycoproteins are involved in viral host binding and subsequent virus-host membrane fusion to establish the pathogenesis of the virus. Two envelope glycoproteins, namely E1 and E2 develop the viral spike of the virions of Flaviviridae family [61] are involved in the engagement with host receptor and conformational change required for membrane fusion (Fig. 1c). Studies show that E2 can express independently but E1 is dependent upon E2 in case of HCV. SARS Coronavirus possess a spike(S) glycoprotein [70], which itself performs the membrane fusion for the entry of the virion and its fusion with host cell [115]. In case of Chikungunya virus, attachment is facilitated by the E2 glycoprotein [89] and fusion mainly by the E1 glycoprotein, thus both the processes are mutually exclusive, whereas in Dengue virus, it is carried by the same E protein (http://www.uniprot.org/ uniprot/Q8JUX5). Interestingly, the dengue virus apart from synthesizing the basic capsid, membrane and envelope proteins also produces seven non-structural secretory glycoproteins NS1,2A, 2B, 3, 4A,4B,5 [46]. These proteins are not integrated in the virus but secreted in the host. Studies have found heterogeneity in the E glycoprotein of Dengue virus [56]. Five different glycans are present in this glycoconjugate including Mannose, GalNac and GlcNac, 


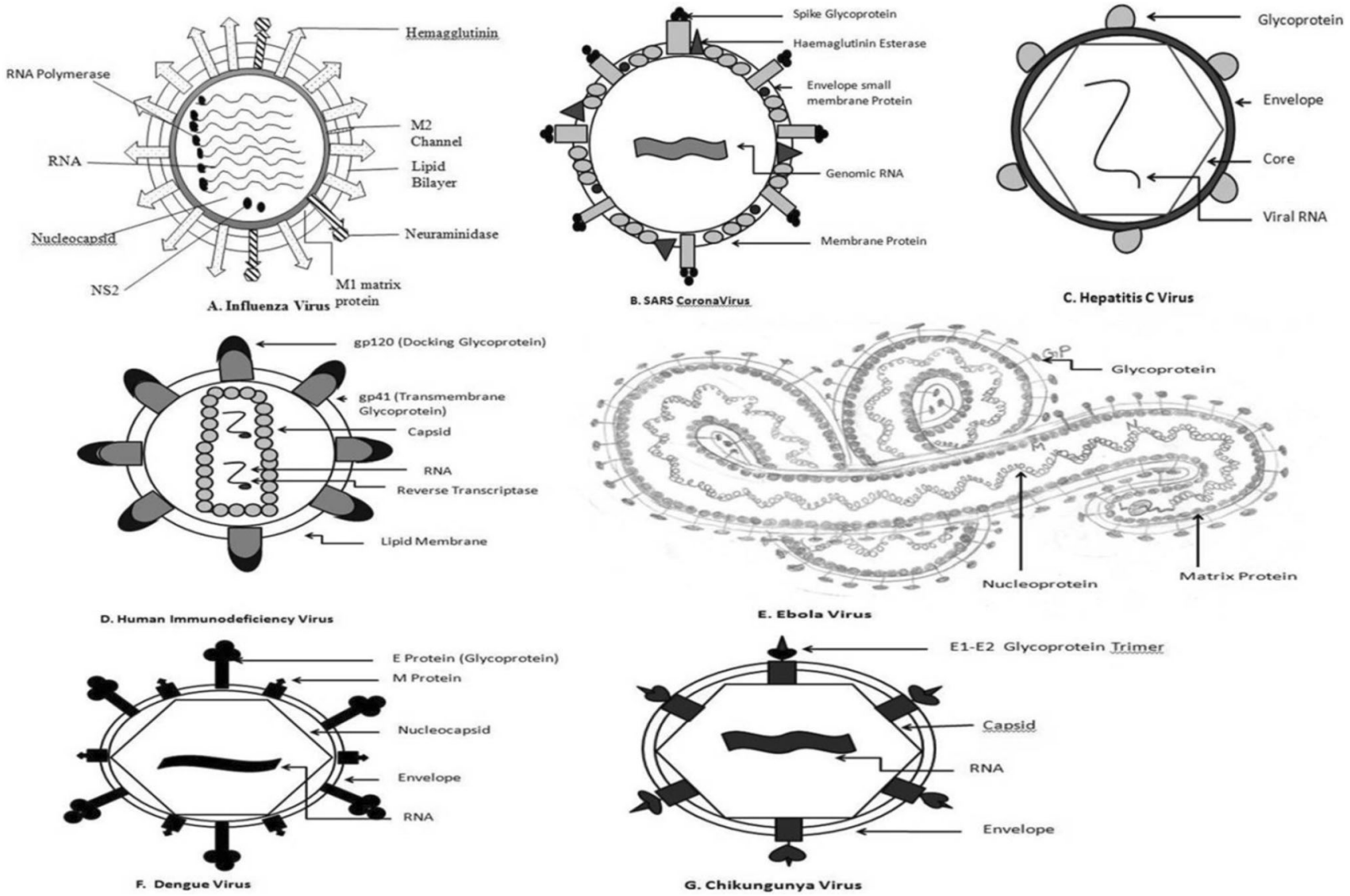

Fig. 1 Distribution of Glycoproteins on the surfaces of different viruses a influenza virus, b SARS Coronavirus, $\mathbf{c}$ Hepatitis $\mathbf{C}$ virus, $\mathbf{d}$ human immunodeficiency virus, e Ebola virus, $\mathbf{f}$ Dengue virus and $\mathbf{g}$ Chikungunya virus

Fucose and Sialic Acid. B cell and T-cell epitopes are predicted in a study by analysing this E glycoprotein [46]. The Dengue Viral envelope is more ordered than the inner viral core, as the envelope is composed of 90 glycoprotein E dimer icosahedral scaffold [58]. Computational studies are there to develop vaccines against Dengue virus $[4,97]$.

There are three glycoproteins present in HIV [1]; namely gp 120, gp 160 and gp 41 [38]. All these are encoded by the ENV gene [76]. The HIV envelope glycoprotein gp120 contains nine disulphide bridges and is highly glycosylated, carrying on average $24 \mathrm{~N}$-linked glycans (Fig. 1d) [73]. Experiments proved that the glycan part of the gp 41 protein has important role in the efficient intracellular transport of another glycoprotein gp 160. Those gp 160 proteins lack gp41 are arrested in golgi complex after their biosynthesis [27]. Zaire Ebola Virus is the member of Filoviridae group, and the Glycoproteins (GP) have found to be major pathogenic determinants [2426, 63, 75, 99]. In the Ebola virion GP gene is the 4th gene among total seven genes in the linear gene order. This synthesizes several proteins. Among them two are predominant. Those are sGP and $\Delta$-peptide (delta peptide). These two proteins are produced due to a furin cleavage of a precursor pre-sGP protein. The GP is actually a Spike protein which is composed of two subunits joined by disulphide linkage Gp1-Gp2 [92].

The Chikungunya Virus on the other hand are known to produce 4 Non structural glycoproteins (nsP1-4) [91] these nsPs have been demonstrated to have important role in keeping the replicase complex of the virus intact in the host as well as to circumvent important host immune responses. Chikungunya Virus has two envelope proteins, namely E1 and E2 [11]. Thus, viral glycoproteins have diverse structure and function. Taken together, glycoproteins are important components of the virus structure and each have unique role to establish pathogenesis. [17].

Viral glycoproteins have a definite role in their pathogenesis. The primary goal of viral infection is to identify a receptor on the host cell surface and binding with it. Subsequently this will pave the way of viral entry into the host cell. In most cases, the first attachment site of the virus is a glycan, either a glycoprotein or a glycolipid. So, glycoproteins play a crucial role in viral pathogenesis. The study of glycoproteins in viral infection is most important to know the disease process as well as to develop antiviral treatments. Glycoprotein-receptor interactions also play 
important roles in pathogen pattern recognition and in the regulatory signals that control the activities of cells of the immune system. The most important cause behind viral infection is that it has evolved to present its own sugars and receptors in a manner that mimics or interferes with host glycan-based immune functions. Glycomic studies are ongoing in several viruses. Several advanced technologies are there to decipher structural and functional aspects of glycans like Glycan microarray [40], Mass Spectrometry and Nano LC. Glycan array represents the actual in vivo interaction in silico. The arrayed multivalent demonstration of polysaccharides mimics the cell surface display. There are two types of carbohydrate microarray. Those are polysaccharide and oligosaccharide microarray [53]. Natural polysaccharides are randomly immobilized on solid matrices exploiting hydrophobic physical absorption or charge-based interaction. Polysaccharide microarrays are useful for comparative antigenicity analyses. Being hydrophilic in nature, oligosaccharides need chemical derivatization before arraying. Through oligosaccharide microarray we can study structure-activity relationships [52]. Microarrays were developed on maleimide-functionalized surfaces using seven thiol-containing synthetic highmannose oligosaccharides for the identification of human immunodeficiency virus (HIV) vaccine candidate antigens [2]. The binding profile reveals that several proteins which interact with gp120 of HIV, like the receptor of the innate immune system known as DC-SIGN (CD 209). In case of Influenza glycans, there are protocols for fluorescent labeling of virus, coupling of virus to a glycan microarray, analysis of a glycan microarray slide experiment, and data interpretation. Studies have shown that there are $\alpha 2$, 3-linked sialic acid motif (SA2, 3Gal) in avian, equine, and canine species. Whereas $\alpha 2,6$-linked sialic acid motif (SA2, 6Gal) is present in humans. SA 2 2, 3Gal and $\mathrm{SA} \alpha 2,6 \mathrm{Gal}$ are present in swine, these are causing corresponding host tropism. Zhao et al. [117] showed that, association mining results of glycan microarray [2] data with 211 influenza viruses from five host groups: humans, swine, canine, migratory waterfowl, and terrestrial birds [72]. The study suggest that besides Neu5Ac $\alpha 2-6 \mathrm{Gal} \beta$, human-origin viruses could bind glycans with Neu5Ac $\alpha 2-$ 8Neu5Ac $\alpha 2-8$ Neu5Ac and Neu5Gc $\alpha 2-6$ Gal $\beta 1-4 G l c N A c$ substructures; Gal $\beta$ and GlcNAc $\beta$ terminal substructures, without sialic acid branches these were linked with the binding of human, swine, and avian origin viruses. Sulfated Neu5Aca2-3 substructures were associated with the binding of human- and swine-origin viruses. Finally, through three-dimensional structure characterization, it has been revealed that the role of glycan chain shapes is more important than that of torsion angles [117].

Though characterization of Glycoproteins is tough but, through Mass Spectrometry, it is now easier to identify structural details of complex glycoproteins. Mass spectrometry derived glycoproteomics [118] helps us to precisely identify viral and cellular proteins that are functionally, structurally, and dynamically altered during virus infection, but enables us to identify important proteins having active role in the infection pathway. Additionally, isolation and purification techniques along with quantitative strategies in conjunction with MS significantly improve its sensitivity to detect low-abundant proteins. With time, more virus and host genomes are being sequenced and MS-based glycoproteomics is becoming a very important tool for virology. A work by Barrientos et al. [7] revealed that post translational modification of secretory glycoprotein of Zaire Ebola Virus can be characterized by Mass spectrometry. MALDI-TOF MS (Matrix-assisted laser desorption/ionization-time-of-flight mass spectrometry) also enables to identify regions susceptible to limited proteolysis in sGP of $\mathrm{ZEV}$.

Another work by Anastassia et al. [54] shows that 0.1 microgram of viral glycoprotein can be purified by NanoLiquid Chromatography. After Nano-LC the sample is analysed through mass spectrometry. One more work showed that they purified Heat shock protein 90 by NanoLC-MS of Respiratory syncitial virus which have important role in virus particle assembly [54, 80]. So it is evident that using these modern techniques, the biological roles of glycoproteins can be studied more conveniently.

\section{Viral glycoproteins and their biological role}

Virus is a nucleic acid surrounded by proteins. This infective particle is called a virion. In most cases this virion is covered with a fascinating coat composed of glycoproteins through which the virus communicates with its host. The co-evolution of host and virus leads the way of making the glycoprotein coat so fascinating [23]. It is evident that the infectivity of a virus rather of its nucleic acid is fully dependent on its glycoproteins. Enveloped viruses generally encode membrane proteins and these special proteins are necessary to mediate the specific binding against host cell ligands. This also directs initial events of membrane fusion and viral internalization. These fascinating envelope proteins are generally glycosylated [15]. The process of glycosylation takes place in the endoplasmic reticulum (ER)-Golgi complex secretory pathway. The host cell encoded glycosyl-transferase enzyme catalyses the glycosylation. This glycosylation is necessary to make the virion host compatible, which is needed by the virus for its pathogenesis. So glycans present at the envelop proteins acts as immunological barriers to resist evasion by the host immune system [22]. 
Several Viruses exhibit different glycoproteins on their surface (Table 1). Hepatitis C Virus has two envelope glycoproteins namely E1 and E2 [59, 98]. These two proteins play an important role in viral infectivity and can be used as candidate subunit vaccine [98]. On the other hand, in case of Ebola virus there are glycoproteins GP1 and GP2 which causes cell attachment and cell fusion and therefore the main target of the host antibodies. The Ebola virus has an RNA editing mechanism to regulate these GP 1 and 2 genes which when expressed at high level, disrupts normal cell physiology [24]. In case of HIV-1, the gp-120 protein initiates viral entry to the CD4 cells [16]. Recent studies proved that several types of glycans in HIV-1 produce different levels in infectivity. Those viruses have more oligomannose and less structural complexity, infects more efficiently. This ultimately proves that mature oligosaccharide structure of the envelope glycans play a pivotal role in the infection process of HIV-1. Due to $N$-linked glycosylation of gp-160 protein in the endoplasmic reticulum, and further folding and cleaving in the golgi complex; the gp-120 protein of the envelope is produced [71].

There are two popular glycoproteins present on the surface of Influenza virus namely, Haemaglutinin (HA) and Neuraminidase (NA) $[84,88]$. These are the key molecules for the viral infection which binds with Sialic acid.
Initially, HA binds with sialic acid during the initiation of infection. After viral replication NA degrades its substrate sialic acid to accelerate release of new viruses [30].

So it is evident from the examples of viruses of diverse family that glycoproteins are the key molecules for a virus to establish an infection within the host and to survive further within the host system.

In the study of viral pathogenesis, a special type of glycoprotein, called Semaphorin have been established [6]. Semaphorins are family of cell surface signaling glycoproteins which binds to the family of plexin glycoprotein cell surface receptors. Semaphorins also activate repulsive guidance pathways having active part in axon guidance, immune regulation and activation, and vascular development [57, 93]. Semaphorins have eight known classes. Among them two are found in invertebrates, five in vertebrates, and the eighth class in viruses which are known as 'viral semaphorins' [19]. The ectodomains of cellular semaphorins contain C-terminal domain elaborations like PSI (plexin, semaphorin and integrin) domains, immunoglobulin (Ig)-like domains, thrombospondin domains and PDZ-domain-binding sites which occassionally attach to the cell-surface. Whereas the N-terminal having a plexin-binding sema-domain, is conserved in all cases of virus host cell attachment. The sema-domain is the

Table 1 Status of glycoproteins in some well studied viruses and their disease burden

\begin{tabular}{|c|c|c|c|}
\hline Name of the Virus & $\begin{array}{l}\text { Glycoproteins } \\
\text { identified }\end{array}$ & Specific role & Disease burden \\
\hline Influenza virus & $\begin{array}{l}\text { Haemaglutinin and } \\
\text { Neuraminidase } \\
{[18,43]}\end{array}$ & $\begin{array}{l}\text { Fusion with host cell membrane } \\
\text { Sialic Acid and attachment [43] }\end{array}$ & 3-5 million cases Worldwide $[78,105]$ \\
\hline SARS-CoV & $\begin{array}{l}\text { Spike(S) glycoprotein } \\
{[25,115]}\end{array}$ & Membrane fusion [115] & $\begin{array}{l}8422 \text { within the duration of } 1 \text { st November } 2002 \text { to } 7 \text { th } \\
\text { August } 2003 \text { occurring worldwide }[113,114]\end{array}$ \\
\hline Hepatitis $\mathrm{C}$ virus & E1 and E2 $[55,98]$ & $\begin{array}{l}\text { Binding to Host receptor and } \\
\text { Conformational change necessary } \\
\text { for membrane fusion [98] }\end{array}$ & 130 to 150 million people globally $[103,106]$ \\
\hline $\begin{array}{l}\text { Human } \\
\text { immunodeficiency } \\
\text { virus } 1\end{array}$ & $\begin{array}{l}\text { gp120, gp160, } \\
\text { gp41 [16] }\end{array}$ & Intracellular transport [16] & 35 million globally up to $2013[83,104,108,112]$ \\
\hline Zaire Ebola virus & $\begin{array}{l}\text { Spike Protein } \\
\text { Gp1-Gp2 [64] }\end{array}$ & Primary Host cell activation [64] & up to 28 th June 2015 total 27,550 cases $[107,110,111]$ \\
\hline Dengue virus & $\mathrm{E}$ (dimer) [64] & Host cell fusion and attachment [64] & $\begin{array}{l}\text { WHO reported recently that there are } 390 \text { million dengue } \\
\text { infections per year globally [109]. Presently Dengue is } \\
\text { endemic in } 112 \text { countries [109]. }\end{array}$ \\
\hline Chikungunya virus & E1 and E2 $[41,51]$ & Host cell binding & $\begin{array}{l}\text { According to WHO, this disease occurs mainly in Africa, } \\
\text { Asia and Indian Sub-continent [102]. But recently in } \\
\text { the } 2005 \text { outbreak around the Indian Ocean, there were } \\
\text { imported cases in Europe and USA through travellers. } \\
\text { In } 2005 \text { there were } 1.9 \text { million reported cases around } \\
\text { Indian Ocean [102]. On 21st October } 2014 \text { France has } \\
\text { reported } 4 \text { local Chikungunya infections and in late } \\
2014 \text { there was an outbreak in the pacific islands [102]. } \\
\text { In India, NVBDCP reports that up to 29th June 2015 } \\
\text { there were 10,317 total suspected Chikungunya cases. }\end{array}$ \\
\hline
\end{tabular}


only component found in viruses. Crystallographic studies by Bowden et al. [10] have revealed that human Sema3A and mouse Sema4D semadomains comprises of structurally conserved homodimer of seven-bladed $\beta$-propellers $[6,50$, $65,69,77]$. The immune-regulatory semaphorins like Sema3A, 4A, 4D, and 7A helps in B cell mediated immunity (Sema4D), T cell activation as well as differentiation (Sema4A, Sema3A, and Sema4D), and inflammation (Sema7A) [93]. These semaphorins provide a molecular basis for how viruses can optimize their own proteins to override normal physiological interactions.

A work by Shirato $\mathrm{H}$ as 'Norovirus and histo-blood group antigens' in the journal Jpn $\mathrm{J}$ Infect Dis. (2011;64(2):95-103) describes that NoroVirus (NoV) causes viral gastroenteritis and interestingly bind to histoblood group antigens (HBGAs), like ABH antigens and Lewis antigens. It has been shown epidemiologically that persons with different $\mathrm{ABH}$ phenotypes are infected with NoV strains in a genotype-dependant fashion. An in vitro binding assay using NoV virus-like particles (VLPs) showed a uniform recognition pattern for type 1 and 2 core structures of histo blood group antigens. NoV VLPs bind more tightly to type 1 carbohydrates than to type 2 . Type 1 carbohydrates are found to be expressed at the surface of the small intestine and targeted by NoV. This property speaks about NoV tissue specificity.

So it is evident that glycoproteins perform a major and active role in viral pathogenesis and disease progression.

Glycoproteins provide tissue tropism to the virus. Some virues used to infect the respiratory system whereas some affects the liver. The cause is the type of glycoprotein with which the virus binds to accelerate its invasion.

In a study by Raska et al. [81], it has been proved that there are differential glycosylation in viruses like HIV1 depending upon the cells which produce the virus. $\mathrm{N}$-glycosylation of reconbinant gp120 of HIV1 is varied and affected the recognition by serum antibodies. Glycosylation of gp120 protein of HIV1 affects its recognition by neutralizing and non neutralizing monoclonal antibodies. This study also says that this glycosylation is cell specific.

Another study by Lin et al. [64] stated that there are C-type lectins expressed on the Dendritic Cell surface known as DC-SIGN(Dendritic Cell-Specific Intercellular adhesion molecule-3-Grabbing Non-integrin) or CD 209 and DC-SIGNR which binds to HIV1 and transmit to T cells through the viral envelope Env glycoprotein. But interestingly other highly glycosylated Viruses failed to interact with DC-SIGNR [64]. Lin et al. showed that DCSIGN (R) or CD 209 selectively binds with HIV1 Env and Zaire Ebola Virus glycoproteins containing more highmannose. By modulating N-glycans on Env or glycoprotein during virus production in different primary cells or in the presence of the mannosidase I inhibitor deoxymannojirimycin affected DC-SIGN(R) infectivity enhancement. They also predict that viruses containing glycoproteins with a high amount of high-mannose $\mathrm{N}$-glycans effectively interact with DC-SIGN(R), but those viruses having only complex $\mathrm{N}$-glycans cannot effectively react with DCSIGN(R). So it is evident that virus-producing cell type is a crucial factor in depicting both $\mathrm{N}$-glycan status and virus interactions with DC-SIGN $(\mathrm{R})$, which establishes virus tropism and infection within the human body [64].

Liu et al. [66] described in their study that sialic acid present on cell surface is essential for Human EnteroVirus D 68 (EV-D68) entry. Crystallographic studies showed that EV-D68 with sialylated glycan receptor analogues binds on the viral surface. Sialic acid receptor induces a cascade of conformational changes within the virus to secrete a fattyacid-like molecule which regulates the stability of the virus. So, it is evident that binding of virus to a sialic acid receptor and to immunoglobulin-like receptors facilitates viral entry in enteroviruses.

\section{Application of viral glycoproteins in diagnostics}

Glycan based viral immunodiagnostics usually have high sensitivity and specificity. Glycoprotein based IgM serology was developed for the diagnosis of recent primary rubella virus infections and significant sensitivity and specificity was obtained. Similarly, Glycoprotein based serology tests to detect antibodies to herpes simplex virus glycoproteins G-1 and G-2, which evoke a type-specific antibody response have also been developed. These tests are used to confirm a diagnosis of genital herpes, and also to establish diagnosis of HSV infection in patients with atypical complaints, to identify asymptomatic carriers, and identify persons at risk for acquiring HSV. Glycan based immunodiagnostics have also been developed for the rapid identification of different strains of Influenza Virus. A novel peptide based ELISA which has sensitivity and specificity of 96.55 and $74.4 \%$ respectively is very promising. On the other hand, the main diagnostic challenge related to SARS is to diagnose it differently with atypical pneumonia $[68,79]$. The key diagnostic tools are immunofluorescent staining, ELISA and RT-PCR [67]. But all these techniques are extremely sophisticated and of little use in case of epidemics; especially in the developing world. SARS Coronavirus possess a spike(S) glycoprotein, which itself performs the membrane fusion for the entry of the virion and its fusion with host cell (Fig. 1b) [115]. IgG based diagnostics against this $\mathrm{S}$ protein has been developed [114]. Indirect ELISA test has been developed by using recombinant SARS ' $\mathrm{S}$ ' protein and the $\mathrm{N}$ (nucleoprotein) protein. The sensitivity of SARS ' $\mathrm{S}$ ' and ' $\mathrm{N}$ ' proteins are 
100 and $96.7 \%$ respectively whereas the specificity of SARS 'S' and 'N' are 98.55 and $98.4 \%$ [114].

Similarly, as acute Hepatitis C infection is asymptomatic, so it is difficult to diagnose early. Generally patients come to the clinic with damaged liver. Initially patients are screened by anti-HCV antibody test and further confirmed by testing Viral RNA. There are two glycoproteins E1 and E2 in HCV. Standardised PCR system is available in $\mathrm{HCV}$ diagnostics but a Core antigen test is also in the market. In 1995 Tanaka et al. [21] suggested that the $\mathrm{HCV}$ core proteins can be used as antigens for the chronic stage. Studies for developing Algorithms confirms $99.05 \%$ sensitivity in case of RT-PCR whereas $98.10 \%$ for the Core Antigen Test [82]. Another novel glycoproteomic serum biomarker has been identified which can diagnose $\mathrm{HCV}$ along with progressive liver cirrhosis is Wisteria floribunda agglutinin positive Mac-2-binding protein (WFA+-M2BP) [29]. The diagnostic threshold for cut-off index values of this protein is 1.435 and 4.615 in $\mathrm{HCV}$ negative and $\mathrm{HCV}$ positive patients showing progressive liver cirrhosis [39].

In case of HIV1, ELISA and PCR are two Gold standard tests. Type specific conformational epitopes of the gp160 and gp 41 glycoproteins of the HIV envelope are used for the recognition of 'early HIV antibodies' [14]. Enzyme Immuno assay (EIA) and RT-PCR are used in these assays. These tests are very specific but they fail to diagnose early infection [14]. The most challenging part in HIV diagnosis is to diagnose the acute stage and differentiate "Window Phase" patients from the serologically positive patients [87]. Popular Serological tests fail to diagnose all patients of HIV as they exploit the GAG proteins which literally decrease after disease progression $[60,74]$. There are three glycoproteins present in HIV; namely gp 120, gp 160 and gp 41. All these are encoded by the ENV gene [76]. The HIV envelope glycoprotein gp120 contains nine disulphide bridges and is highly glycosylated, carrying on average 24 $\mathrm{N}$-linked glycans (Fig. 1d) [73]. Experiments proved that the glycan part of the gp 41 protein has important role in the efficient intracellular transport of another glycoprotein gp 160. Those gp 160 proteins lack gp41 are arrested in golgi complex after their biosynthesis [27]. As stated above, there are limitations of the popular GAG antigen based serological tests which cannot diagnose HIV patients of different clinical stage. But antibodies against precursor gp160 ENV protein and final ENV proteins gp 120 and gp 41 can detect all clinical stages of HIV [74]. The Sensitivity of current available diagnostic system is $38 \%$ at $<7$ days, $97 \%$ at $7-41$ days and $95 \%$ at $42-93$ days [74] The Specificity is almost $95 \%$ [90].

In case of Zaire Ebola Virus, initially there was controversy about the role of glycoproteins in the pathogenesis of EBV. But later on, scientific researches proved that the primary host cell activation by the EBV is mediated by GP1-2 [100]. An antigen capture ELISA has been developed in Zaire EBOV using mAbs [85]. It has been reported that these tests have both high sensitivity and specificity [85].

Similarly, Dengue (DENV) NS1 is a highly conserved glycoprotein, expressed as both membrane-associated and secreted forms [33, 36, 94]. Secreted NS1 has been detected ranging from $2-0.04 \mu \mathrm{g} / \mathrm{mL}$ in the serum of dengue-infected patients during the early stages of the disease. A high NS1 level has been demonstrated to circulate as early as 1 day after onset of symptoms up to early convalescences thus provides an alternative to virus culture or PCR for early dengue diagnosis when $\operatorname{IgM}$ or $\operatorname{IgG}$ antibodies are not present yet in dengue infected patients $[42,49]$. Circulating dengue NS1 in sera can be detected either using ELISA assay or lateral flow based RDTs [31]. Thus, glycan based Viral Immunodiagnostics or GlycoImmunodiagnostics are helpful in early diagnosis of patients with viral infection [28].

Current diagnosis scenario in Chikungunya is $\operatorname{IgM}$ and IgG based ELISA and Nucleic Acid detection by RT-PCR $[12,51]$. But there is no Antigen based ELISA. This makes the condition crucial as the primary health care providers in the Virus affected countries do not have RT-PCR facilities. It is not recommended to maintain RT-PCR facilities in Primary Health care centre by policy. It is extremely costly and demands expertise. It is not possible to provide such facility in the densely populated tropical countries. As Chikungunya causes short duration fever, often the patients are not diagnosed properly. The joint pain generally persists for some days but can be present for a year [102]. There is a study which shows even multi organ failure in Chikungunya infected patients [45]. CHIKV has two envelope glycoproteins, namely E1 and E2 (Fig. 1g) [11]. Recombinant CHIKV E1 and E2 glycoprotein based ELISA showed a sensitivity of 77.5 and $90 \%$ respectively whereas the specificity for both cases was $100 \%[11,54]$ highlighting the potential for these two glycoproteins in the diagnosis.

\section{Conclusion}

Viral glycoproteins are integral parts of enveloped viruses and they actively take part in their pathogenesis. Exploting glycoproteins, viruses enter into their host and combat with host immune system. Recent advances in technology deciphers different role of glycoproteins which are dependent on their structures.

Different viruses have different mode of pathogenesis and glycoproteins directly takes part in the host binding and entry. During maturation from host cell viruses have 
host glycoproteins on their surface to avoid the immunity of the host. So, to detect viruses and to decide for developing vaccines [37], glycoproteins always play a key role.

Antibody production is a prominent feature of the immune response in patients with viral infection, and particular isotypes correlate with resistance or susceptibility to infection [101]. A substantial proportion of the antibodies detected in patients with acute or chronic infections is directed against viral glycan epitopes. As levels of anti glycan antibody are high and specific for each viral infection this permits diagnostic discrimination between the different viral infections. Taken together, viral glycoproteins have important functions in pathogenesis and can be exploited to develop viral diagnostics.

Acknowledgments Mr. Nilotpal Banerjee is a recipient of Junior Research Fellowship from Department of Biotechnology [File No. 232/BT(Estt.)/RD-24/2014], Government of West Bengal, India.

\section{References}

1. About HIV/AIDS, HIV BASICS, CDC. http://www.cdc.gov/hiv/ basics/whatishiv.html. Accessed on 1st June 2015.

2. Adams EW, Ratner DM, Bokesch HR, McMahon JB, O'Keefe $\mathrm{BR}$, Seeberger PH. Oligosaccharide and glycoprotein microarrays as tools in HIV glycobiology; glycan-dependent gp120/ protein interactions. Chem Biol. 2004;11(6):875-81.

3. Alonso WJ, Laranjeira BJ, Pereira SAR, Florencio CMGD, Moreno EC, Miller MA, Gigilo R, Schuch-Paim C, Moura FEA. Comparative dynamics, morbidity and mortality burden of pediatric viral respiratory infections in an equatorial city. Pediatr Infect Dis J. 2012;31:e9-14. doi:10.1097/INF. 0b013e31823883be.

4. Amat-ur-Rasool H, Saghir A, Idrees M. Computational prediction and analysis of envelop glycoprotein epitopes of DENV-2 and DENV-3 Pakistani isolates: a first step towards dengue vaccine development. Samuel JE, ed. PLoS One. 2015;10: $\mathrm{e} 0119854$

5. Amon R, Reuven EM, Ben-Arye SL, Padler-Karavani V. Glycans in immune recognition and response. Carbohydr Res. 2014;7(389):115-22.

6. Antipenko A, Himanen JP, van Leyen K, Nardi-Dei V, Lesniak J, Barton WA, Rajashankar KR, Lu M, Hoemme C, Puschel AW, Nikolov DB. Structure of the semaphorin-3A receptor binding module. Neuron. 2003;39:589-98.

7. Barrientos LG, Martin AM, Pierre W, Rollin E. Secreted glycoprotein from live zaire ebolavirus-infected cultures: preparation, structural and biophysical characterization, and thermodynamic stability. J Infect Dis. 2007;196(Supplement 2):S220-31.

8. Baumgarten A. Viral immunodiagnosis. Yale J Biol Med. 1980;53(1):71-83.

9. Biernat B, Stańczak J, Szostakowska B, Wroczyńska A, Kuna A, Nahorski WL, Racewicz M. Different serotypes of dengue virus (DENV) imported by Polish travellers from dengue endemic areas to Poland. Int Marit Health. 2015;66:72-6.

10. Bowden TA, Jones EY, Stuart DI. Cells under siege: viral glycoprotein interactions at the cell surface. J Struct Biol. 2011;175:120-6.
11. Byungki C, Jeon BY, Kim J, Noh J, Kim J, Park M, Park S. Expression and evaluation of Chikungunya virus E1 and E2 envelope proteins for serodiagnosis of Chikungunya virus infection. Yonsei Med J. 2008;49:828-35.

12. Caglioti C, Lalle E, Castilletti C, Carletti F, Capobianchi MR, Bordi L. Chikungunya virus infection: an overview. New Microbiol. 2013;36:211-27.

13. CDC (2000), MMWR, Interpretation and Use of the Western Blot Assay for Serodiagnosis of Human Immunodeficiency Virus Type 1 Infections, http://www.cdc.gov/mmwr/preview/ mmwrhtml/00001431.htm.

14. Chen J, Wang L, Chen JJ, Sahu GK, Tyring S, Ramsey K, Indrikovs AJ, Petersen JR, Paar D, Cloyd MW. Detection of antibodies to human immunodeficiency virus (HIV) that recognize conformational epitopes of glycoproteins 160 and 41 often allows for early diagnosis of HIV infection. J Infect Dis. 2002;186:321-31.

15. Chikungunya Virus, Centers for disease control and prevention. http://www.cdc.gov/chikungunya/.

16. Chirmule N, Pahwa S. Envelope glycoproteins of human immunodeficiency virus type 1: profound influences on immune functions. Microbiol Rev. 1996;60:386-406.

17. Cifuentes-Muñoz N, Salazar-Quiroz N, Tischler ND. Hantavirus Gn and Gc envelope glycoproteins: key structural units for virus cell entry and virus assembly. Viruses. 2014;6:1801-22.

18. Collins JK, Knight CA. Purification of the influenza hemagglutinin glycoprotein and characterization of its carbohydrate components. J Virol. 1978;26:457-67.

19. Comeau MR, Johnson R, DuBose RF, Petersen M, Gearing P, VandenBos T, Park L, Farrah T, Buller RM, Cohen JI, Strockbine LD, Rauch C, Spriggs MK. A poxvirus-encoded semaphorin induces cytokine production from monocytes and binds to a novel cellular semaphorin receptor. VESPR. Immunity. 1998;8:473-82.

20. Das R. Ebola to have a global burden of $\$ 5.9$ Billion By End Of 2016, Forbes, Pharma \& Healthcare, Nov 12, 2014 @ 03:14 PM. http://www.forbes.com/sites/reenitadas/2014/11/12/ebola-tohave-a-global-burden-of-5-9-billion-by-end-of-2016/. Accessed on 1st June 2015.

21. Dawson GJ. Detection of HCV core antigen, Abbott http://www. cdc.gov/hepatitis/resources/mtgsconf/hcvsymposium2011-pdfs/ 7_dawson.pdf.

22. De Haan CAM, Vennema H, Rottier PJM. Assembly of the coronavirus envelope: homotypic Interactions between the M proteins. J Virol. 2000;74:4967-78.

23. Dengue: Guidelines for Diagnosis, Treatment, Prevention and Control: New Edition. Geneva: World Health Organization; 2009. 4, Laboratory diagnosis and diagnostic tests. Available from: http://www.ncbi.nlm.nih.gov/books/NBK143156/.

24. Dolnik O, Volchkova VA, Escudero-Perez B, Lawrence P, Klenk HD, Volchkov VE. Shedding of Ebola virus surface glycoprotein is a mechanism of self-regulation of cellular cytotoxicity and has a direct effect on virus infectivity. J Infect Dis. 2015;212(suppl_2):S322-8.

25. Dong PH, Kima HG, Kima Y, Poonb LLM, Cho MW. Development of a safe neutralization assay for SARS-CoV and characterization of S-glycoprotein. Virology. 2004;326:140-9.

26. Feldmann H, Volchkov VE, Volchkova VA, Stroher U, Klenk HD. Biosynthesis and role of filoviral glycoproteins. J Gen Virol. 2001;82:2839-48.

27. Fenouillet E, Jones IM. The glycosylation of human immunodeficiency virus type 1 transmembrane glycoprotein (gp41) is important for the efficient intracellular transport of the envelope precursor gp160. J Gen Virol. 1995;76:1509-14.

28. Flamand M, Megret F, Mathieu M, Lepault J, Rey FA, Deubel V. Dengue virus type 1 nonstructural glycoprotein ns1 is 
secreted from mammalian cells as a soluble hexamer in a glycosylation-dependent fashion. J Virol. 1999;73(7):6104-10.

29. Fujiyoshi M, Kuno A, Gotoh M, Fukai M, Yokoo H, Kamachi H, Kamiyama T, Korenaga M, Mizokami M, Narimatsu H, Taketomi A. Clinicopathological characteristics and diagnostic performance of Wisteria floribunda agglutinin positive Mac-2binding protein as a preoperative serum marker of liver fibrosis in hepatocellular carcinoma. $\mathrm{J}$ Gastroenterol. 2015;50(11):1134-44.

30. Gamblin SJ, Skehel JJ. Influenza hemagglutinin and neuraminidase membrane glycoproteins. J Biol Chem. 2010;285:28403-9.

31. Gelanew T, Poole-Smith BK, Hunsperger E. Development and characterization of mouse monoclonal antibodies against monomeric dengue virus non-structural glycoprotein 1 (NS1). J Virol Methods. 2015;222:214-23.

32. Gelderblom HR. Structure and classification of viruses. In: Baron S, editor. Medical microbiology. 4th ed. Galveston (TX): University of Texas Medical Branch at Galveston; 1996. Chapter 41.

33. Ghosh A, Dar L. Dengue vaccines: challenges, development, current status and prospects. Indian $\mathrm{J}$ Med Microbiol. 2015;33:3-15.

34. Giller HR, Stanley W, Charles G. Cellular and humoral immunity to varicella zoster virus glycoproteins in immune and susceptible human subjects. J Infect Dis. 1989;160(6):919-28.

35. Gubler DJ. Human arbovirus infections worldwide. Ann N Y Acad Sci. 2001;951:13-24.

36. Gurugama P, Garg P, Perera J, Wijewickrama A, Seneviratne SL. Dengue viral infections. Indian J Dermatol. 2010;55:68-78.

37. Hamborsky J, Kroger A, Wolfe C. Influenza, epidemiology and prevention of vaccine-preventable diseases. In: The Pink Book: course textbook. 13th ed. (2015), Centers for Disease Control and Prevention, April 2015. http://www.cdc.gov/vaccines/pubs/ pinkbook/downloads/flu.pdf.

38. Hansen JE. Carbohydrates of human immunodeficiency virus. APMIS Suppl. 1992;27:96-108.

39. Harvey David J. Analysis of carbohydrates and glycoconjugates by matrix-assisted laser desorption/ionization mass spectrometry: an update for 2007-2008. Mass Spectrom Rev. 2012;31(2):183-311.

40. Heimburg-Molinaro J, Tappert M, Song X, Lasanajak Y, Air G, Smith DF, Cummings RD. Probing virus-glycan interactions using glycan microarrays. Methods Mol Biol. 2012;808:251-67.

41. Her Z, Kam YW, Lin RT, Ng LF. Chikungunya: a bending reality. Microbes Infect. 2009;11:1165-76.

42. Hermann LL, Thaisomboonsuk B, Poolpanichupatam Y. Evaluation of a dengue NS1 antigen detection assay sensitivity and specificity for the diagnosis of acute dengue virus infection. Harris E, ed. PLoS Negl Trop Dis. 2014;8:e3193.

43. Hidari KIPJ, Suzuki T. Glycan receptor for influenza virus. Open Antimicrob Agents J. 2010;2:26-33.

44. Hobson-Peters J. Approaches for the development of rapid serological assays for surveillance and diagnosis of infections caused by zoonotic flaviviruses of the japanese encephalitis virus serocomplex. J Biomed Biotechnol. 2012;2012:15, Article ID 379738 .

45. Hoz JM, Bayona B, Viloria S, Accini JL, Juan-Vergara HS, Viasus D. Fatal cases of Chikungunya virus infection in Colombia: diagnostic and treatment challenges. J Clin Virol. 2015;69:27-9.

46. Hussain M, Idrees M, Afzal S. Development of global consensus of dengue virus envelope glycoprotein for epitopes based vaccine design. Curr Comput Aided Drug Des. 2015;11:84-97.

47. Influenza Symptoms and the Role of Laboratory Diagnostics, Health Professionals, Seasonal. Laboratory diagnostic procedures for testing for influenza (flu)—CDC, http://www. cdc.gov/flu/professionals/diagnosis/labrolesprocedures.htm. Accessed on 1st June 2015.

48. Institute of Medicine (US) Forum on Microbial Threats. Microbial evolution and co-adaptation: A tribute to the life and scientific legacies of joshua lederberg: workshop summary. Washington (DC): National Academies Press (US); 2009. 5, Infectious disease emergence: past, present, and future. Available from: http://www.ncbi.nlm.nih.gov/books/NBK45714/.

49. Jain A, Shah AN, Patel P, Desai M, Somani S, Parikh P, Singhal R, Joshi D. A clinico-hematological profile of dengue outbreak among healthcare Professionals in a tertiary care hospital of Ahmedabad with analysis on economic impact. Nat J Comm Med. 2013;4:286-90.

50. Janssen BJ, Robinson RA, Perez-Branguli F, Bell CH, Mitchell KJ, Siebold C, Jones EY. Structural basis of semaphorin-plexin signalling. Nature. 2010;467:1118-22.

51. Kam Y-W, Lee WWL, Simarmata D. unique epitopes recognized by antibodies induced in Chikungunya virus-infected nonhuman primates: implications for the study of immunopathology and vaccine development. Lu S, ed. PLoS One. 2014; 9(4):e95647.

52. Kamata T, Natesan M, Warfield K, Aman MJ, Ulrich RG. Determination of specific antibody responses to the six species of ebola and marburg viruses by multiplexed protein microarrays. Clin Vaccine Immunol. 2014;21:1605-12.

53. Kamena F, Tamborrini M, Liu X, Kwon Y, Thompson F. Synthetic GPI array to study antitoxic malaria response. Nat Chem Biol. 2008;4:238-40.

54. Komarova AV, Combredet C, Meyniel-Schicklin L, Chapelle M, Caignard G, Camadro J-M, Lotteau V, Vidalain P-O, Tangy F. Proteomic analysis of virus-host interactions in an infectious context using recombinant viruses. Mol Cell Proteomics. 2011;10(12):M110.007443.

55. Kong L, Kadam RU, Giang E, Ruwona TB, Nieusma T, Culhane JC, Stanfield RL, Dawson PE, Wilson IA, Law M. Structure of hepatitis $\mathrm{C}$ virus envelope glycoprotein E1 antigenic site 314-324 in complex with antibody IGH526. J Mol Biol. 2015;427(16):2617-28.

56. Kroschewski H, Sagripanti J, Davidson A. Identification of amino acids in the dengue virus type 2 envelope glycoprotein critical to virus infectivity. J Gen Virol. 2009;90:2457-61.

57. Kruger RP, Aurandt J, Guan KL. Semaphorins command cells to move. Nat Rev Mol Cell Biol. 2005;6:789-800.

58. Kuhn RJ, Zhang W, Rossmann MG. Structure of dengue virus: implications for flavivirus organization, maturation, and fusion. Cell. 2002;108:717-25.

59. Lagging LM, Meyer K, Owens RJ, Ray R. Functional role of hepatitis $\mathrm{C}$ virus chimeric glycoproteins in the infectivity of pseudotyped virus. J Virol. 1998;72:3539-46.

60. Lange JMA, Coutinho RA, Krone WJA. Distinct IgG recognition patterns during progression of subclinical and clinical infection with lymphadenopathy associated virus/human $\mathrm{T}$ lymphotropic virus. Brit Med J. 1986;292:228-30.

61. Lavie M, Goffard A, Dubuisson J. HCV glycoproteins: assembly of a functional E1-E2 Heterodimer. In: Tan SL, editor. Hepatitis $C$ viruses: genomes and molecular biology. Norfolk (UK): Horizon Bioscience; 2006. Chapter 4.

62. Lee N, Lui GCY, Wong KT, Li TCM, Tse ECM, Chan JYC, Yu J, Wong SSM, Choi KW, Wong RYK, Ngai KLK, Hui DSC, Chan PKS. High morbidity and mortality in adults hospitalized for respiratory syncytial virus infections. Clin Infect Dis. 2013;57:1069-77.

63. Leroy EM. Diagnosis of Ebola haemorrhagic fever by RT-PCR in an epidemic setting. J Med Virol. 2000;60:463-7. 
64. Lin G, Simmons G, Pöhlmann S, et al. Differential N-linked glycosylation of human immunodeficiency virus and ebola virus envelope glycoproteins modulates interactions with DC-SIGN and DC-SIGNR. J Virol. 2003;77(2):1337-46.

65. Liu H, Juo ZS, Shim AH, Focia PJ, Chen X, Garcia KC, He X. Structural basis of semaphorin-plexin recognition and viral mimicry from Sema7A and A39R complexes with PlexinC1. Cell. 2010;142:749-61.

66. Liu Y, Sheng J, Fokine A, et al. Structure and inhibition of EVD68, a virus that causes respiratory illness in children. Science (New York, NY). 2015;347(6217):71-4.

67. Lo M, Ng EK. Molecular diagnosis of severe acute respiratory syndrome. Methods Mol Biol. 2006;336:163-75.

68. Loughlin J, Poulios N, Napalkov P, Wegmüller Y, Monto AS. A study of influenza and influenza-related complications among children in a large US health insurance plan database. Pharmacoeconomics. 2003;21:273-83.

69. Love CA, Harlos K, Mavaddat N, Davis SJ, Stuart DI, Jones EY, Esnouf RM. The ligand-binding face of the semaphorins revealed by the high-resolution crystal structure of SEMA4D. Nat Struct Biol. 2003;10:843-8.

70. Mahony JB, Richardson S. Molecular diagnosis of severe acute respiratory syndrome. JMD. 2005;7:551-9.

71. Malaspina A, Collins BS, Dell A, Alter G, Onami TM. Conference report: "functional glycomics in HIV type 1 vaccine design" workshop report, Bethesda, Maryland, April 30-May 1, 2012. AIDS Res Hum Retroviruses. 2013;29(11):1407-17. doi:10.1089/aid.2013.0102.

72. Masalova OV, Klimova RR. Development of monoclonal antibodies to highly pathogenic avian influenza H5N1 virus and their application to diagnostics, prophylaxis, and therapy. Acta Virol. 2011;55:3-14.

73. Mathys L, Balzarini J. Several N-glycans on the HIV envelope glycoprotein gp120 preferentially locate near disulphide bridges and are required for efficient infectivity and virus transmission. Paxton WA, ed. PLoS One. 2015;10:e0130621.

74. McDougal JS, Kennedy MS, Nicholson JKA. Antibody response to human immunodeficiency virus in homosexual men: relation of antibody specificity, titer, and isotype to clinical status, severity of immunodeficiency and disease progression. J Clin Invest. 1987;80:316-24.

75. Mirazimi A. Ebola virus disease: societal challenges and new treatments. J Intern Med. 2015;278:227-37.

76. Mushahwar IK. Human immunodeficiency viruses: molecular virology, pathogenesis, diagnosis and treatment. Elsevier Book, Perspect Med Virol. 2007;13:75-87.

77. Nogi T, Yasui N, Mihara E, Matsunaga Y, Noda M, Yamashita N, Toyofuku T, Uchiyama S, Goshima Y, Kumanogoh A, Takagi J. Structural basis for semaphorin signalling through the plexin receptor. Nature. 2010;467:1123-7.

78. Pandemic (H1N1) 2009-update 103. Disease Outbreak News. World Health Organization. 2010-06-04. Retrieved 2010-10-16. Accessed on 1st June 2015.

79. Poon L, Poon LLM, Guan Y, Nicholls JM, Yuen KY, Peiris JSM. Review, The aetiology, origins, and diagnosis of severe acute respiratory syndrome. Lancet Infect Dis. 2004;4(11):663-71.

80. Radhakrishnan A, Yeo D, Brown G, Myaing MZ, Iyer LR, Fleck R, Boon-Huan TI, Aitken J, Sanmun D, Tang K, Yarwood K, Brink J, Sugrue RJ. Protein analysis of purified respiratory syncytial virus particles reveals an important role for heat shock protein 90 in virus particle assembly. Mol Cell Proteomics. 2010;9(9):1829-48.

81. Raska M, Czernekova L, Moldoveanu Z, et al. Differential glycosylation of envelope gp120 is associated with differential recognition of HIV-1 by virus-specific antibodies and cell infection. AIDS Res Ther. 2014;11:23.

82. Reyes-Méndez MÁ, Juárez-Figueroa L, Iracheta-Hernández P, Medina-Islas Y, Ruiz-González V. Comparison of two diagnostic algorithms for the identification of patients with $\mathrm{HCV}$ viremia using a new HCVantigen test. Ann Hepatol. 2014;13:337-42.

83. Robinson EK, Evans BG. Oral sex and HIV transmission. AIDS. 1999;13:737-8.

84. Russell RJ, Kerry PS, Stevens DJ, Steinhauer DA, Martin SR, Gamblin SJ, Skehel JJ. Structure of influenza hemagglutinin in complex with an inhibitor of membrane fusion. Proc Natl Acad Sci USA. 2008;105:17736-41.

85. Saijo M, Niikura M, Ikegami T, Kurane I, Kurata T, Morikawa S. laboratory diagnostic systems for Ebola and Marburg hemorrhagic fevers developed with recombinant proteins. Clin Vaccine Immunol. 2006;13:444-51.

86. Saldova R, Wormald MR, Dwek RA, Rudd PM. Glycosylation changes on serum glycoproteins in ovarian cancer may contribute to disease pathogenesis. Dis Mark. 2008;25(4-5):219-32.

87. Schito ML, D'Souza MP, Owen SM, Busch MP. Supplementary Article, Challenges for rapid molecular HIV diagnostics. JID 2010:201(Suppl 1:S1-6).

88. Shtyrya YA, Mochalova LV, Bovin NV. Influenza virus neuraminidase: structure and function. Acta Naturae. 2009;1:26-32.

89. Silva LA, Khomandiak S, Ashbrook AW, Weller R, Heise MT, Morrison TE, Dermody TS. A single-amino-acid polymorphism in Chikungunya virus E2 glycoprotein influences glycosaminoglycan utilization. J Virol. 2014;88:2385-97.

90. Simonds RJ. Sensitivity and specificity of a qualitative RNA detection assay to diagnose HIV infection in young infants. AIDS. 1998;12:1545-9.

91. Storch GA. Diagnostic virology. Clin Infect Dis. 2000;31(3):739-51.

92. Sullivan N, Yang ZY, Nabel GJ. Ebola virus pathogenesis: implications for vaccines and therapies. $\mathrm{J}$ Virol. 2003;77:9733-7.

93. Suzuki K, Kumanogoh A, Kikutani H. Semaphorins and their receptors in immune cell interactions. Nat Immunol. 2008;9:17-23.

94. Tan BH, Fu JL, Sugrue RJ. Characterization of the dengue virus envelope glycoprotein expressed in Pichia pastoris. Methods Mol Biol. 2007;379:163-76.

95. Types of Influenza Viruses, Seasonal Influenza (Flu), CDC Three Types of Influenza Viruses-CDC. http://www.cdc.gov/ flu/about/viruses/types.htm. Accessed on 1st June 2015.

96. Upadhyay RK. Biomarkers in Japanese encephalitis: a review. BioMed Res Int 2013; 2013:24, Article ID 591290.

97. Van-Gorp EC, Suharti C, Mairuhu AT, Dolmans WM, van Der Ven J, Demacker PN. Changes in the plasma lipid profile as a potential predictor of clinical outcome in dengue hemorrhagic fever. Clin Infect Dis. 2002;34:1150-3.

98. Varki A, Cummings RD, Esko JD, editors. Essentials of glycobiology. 2nd ed. Cold Spring Harbor (NY): Cold Spring Harbor Laboratory Press; 2009.

99. Wahl-Jensen V, Kurz SK, Hazelton PR. Role of Ebola virus secreted glycoproteins and virus-like particles in activation of human macrophages. J Virol. 2005;79:2413-9.

100. Wahl-Jensen VM, Afanasieva TA, Seebach J, Ströher U, Feldmann H, Schnittler H-J. Effects of Ebola Virus glycoproteins on endothelial cell activation and barrier function. J Virol. 2005;79:10442-50.

101. Wandingera KP, Steinhagena S, Schepera T, Meyera W, Barteltb U, Endersb G. Diagnosis of recent primary rubella virus infections: Significance of glycoprotein-based IgM serology, 
IgG avidity and immunoblot analysis. J Virol Method. 2011;174(1-2):85-93.

102. WHO, Chikungunya, Chikungunya: WHO fact sheet on Chikungunya providing key facts and information on scope of the problem, who is at risk, prevention, WHO response. http:// www.who.int/mediacentre/factsheets/fs327/en/. Accessed on 1st June 2015.

103. WHO, Hepatitis C, Hepatitis $\mathrm{C}$ is a liver disease caused by the hepatitis $\mathrm{C}$ virus: the virus can cause both acute and chronic hepatitis infection, ranging in severity from a mild illness lasting a few weeks to a serious, lifelong illness. http://www.who.int/ mediacentre/factsheets/fs164/en/. Accessed on 1st June 2015.

104. WHO, HIV/AIDS WHO fact sheet on HIV/AIDS with key facts and information on signs and symptoms, transmission, risk factors, testing and counselling, prevention, treatment and WHO response. who.int http://www.who.int/mediacentre/factsheets/ fs360/en/. Accessed on 1st June 2015.

105. WHO, Influenza (Seasonal) WHO fact sheet on influenza: includes key facts, definition, symptoms, transmission, seasonal epidemics, effects, prevention, WHO response. http://www.who. int/mediacentre/factsheets/fs211/en/. Accessed on 1st June 2015.

106. WHO, Prevention and Control of Viral Hepatitis Infection: Framework for Global Action who.int http://www.who.int/hiv/ pub/hepatitis/Framework/en/. Accessed on 1st June 2015.

107. WHO, Urgently needed: rapid, sensitive, safe and simple Ebola diagnostic tests, The goal of interrupting chains of Ebola virus transmission depends heavily on laboratory support. http://www. who.int/mediacentre/news/ebola/18-november-2014-diag nostics/en/. Accessed on 1st June 2015.

108. WHO, data and statistics. http://www.who.int/hiv/data/en/data and statistics Accessed on 1st June 2015.

109. WHO, Dengue and severe dengue, WHO fact sheet dengue and severe dengue provides key facts, definition, provides information on global burden, transmission, characteristics, treatment, prevention and control and WHO response. http:// www.who.int/mediacentre/factsheets/fs117/en/. Accessed on 1st June 2015.

110. WHO, Ebola Situation Reports, http://apps.who.int/ebola/ebolasituation-reports. Accessed on 1st June 2015.

111. WHO, Ebola virus disease, WHO fact sheet on Ebola: key facts, definition, transmission, symptoms, diagnosis, treatment, prevention, WHO response. http://www.who.int/mediacentre/fact sheets/fs103/en/. Accessed on 1st June 2015.

112. WHO, HIV/AIDS, WHO launches new guidelines on HIV testing services. http://www.who.int/hiv/en/. Accessed on 1st June 2015.

113. WHO, Middle East respiratory syndrome coronavirus (MERS$\mathrm{CoV})$ :Summary of Current Situation, Literature Update and Risk Assessment-as of $5 \mathrm{Feb}$ 2015. http://www.who.int/csr/dis ease/coronavirus_infections/mers-5-february-2015.pdf. Accessed on 1st June 2015.

114. WHO, Summary table of SARS cases by country, 1 Nov 2002-7 August 2003 http://www.who.int/csr/sars/country/country2003 08_15.pdf. Accessed on 1st June 2015.

115. Xiao X, Dimitrov DS. The SARS-CoV S glycoprotein. Cell Mol Life Sci. 2004;61:2428-30.

116. Yuan J, Zhang Y, Li J, Zhang Y, Wang L-F, Shi Z. Serological evidence of ebolavirus infection in bats, China. Virol J. 2012;9:236

117. Zhao N, Martin BE, Yang C-K, Luo F, Wan X-F. Association analyses of large-scale glycan microarray data reveal novel hostspecific substructures in influenza A virus binding glycans. Sci Rep. 2015;5:15778. doi:10.1038/srep15778.

118. Zheng J, Tan BH, Sugrue R, Tang K. Current approaches on viral infection: proteomics and functional validations. Front Microbiol. 2012;3:393. 